\title{
SARGON OF AKKADE AND HIS GOD
}

\section{COMMENTS ON THE WORSHIP OF THE GOD OF THE FATHER AMONG THE ANCIENT SEMITES}

\author{
STEFAN NOWICKI \\ Institute of Classical, Mediterranean and Oriental Studies, University of Wrocław \\ ul. Szewska 49, 50-139 Wrocław, Poland \\ e-mail: stefan.nowicki@uwr.edu.pl
}

\begin{abstract}
The expression "god of the father(s)" is mentioned in textual sources from the whole area of the Fertile Crescent, between the third and first millennium B.C. The god of the fathers - aside from assumptions of the tutelary deity as a god of ancestors or a god who is a deified ancestor - was situated in the centre and the very core of religious life among all peoples that lived in the ancient Near East. This paper is focused on the importance of the cult of Ilaba in the royal families of the ancient Near East. It also investigates the possible source and route of spreading of the cult of Ilaba, which could have been created in southern Mesopotamia, then brought to other areas. Hypothetically, it might have come to the Near East from the upper Euphrates.
\end{abstract}

Key words: religion, Ilaba, royal inscriptions, Sargon of Akkade, god of the father, tutelary deity, personal god.

The main aim of this study is to trace and describe the worship of a "god of the father", known in Akkadian sources under the name of Ilaba, and his place in the religious life of the ancient peoples belonging to the Semitic cultural circle. Such a description will be based on ancient Near Eastern textual sources from Akkad, Mari, Hana and Ugarit. Some Biblical sources, as auxiliary material, will also be included, but all non-Semitic sources will be disregarded, as well as those in which tutelary deities were mentioned, but their names were not based on the Semitic root ' $l b$. The inclusion and treatment of the latter sources would unduly have exceeded the reasonable size of this paper.

\section{General Remarks}

Around 2350 B.C. a state emerged in southern Mesopotamia, today known as OldAkkadian, the creator of which was Sargon of Akkade, the founder of a new dynasty, 
who also established new political entities among the old Sumerian city-states. ${ }^{1}$ The capital city of this state, which grew within a very short time into the territory that included almost the whole world known at the time, was the city of Akkade, still undiscovered, but probably founded somewhere on the bank of the Tigris (see Sallaberger 1999 , p. 35, note 65 and Wall-Romana 1990, p. 206). The interesting fact about it is that the settlement is thought to be older than Sargon's time, so he was not the founder, he only developed an already existing settlement (Wall-Romana 1990, p. 207; Kuhrt 2000, p. 44). ${ }^{2}$ A very serious problem for contemporary research is the glaring scarcity of sources - in comparison with other historical periods - especially in the case of textual sources of unquestionable historical value. Only tiny fragments of texts have been discovered, which are mostly economic, some remnants of architectural structures, small artefacts and letters (see Foster 1982, p. 7). ${ }^{3}$ The longest readable source from the Sargonic period, found so far, is a list of daily rations of food for workers, which was discovered in Ešnunna during the excavations led by the Oriental Institute of the University of Chicago between 1930 and 1938 (Gelb 1952, p. 163; Visicato 1997, p. 238). Another problem is the small number of archives, the role of which in the studies on ancient Mesopotamia cannot be overestimated (Sallaberger 1999, pp. 5696). Recently, there were published some new texts from the Akkadian period, including the renowned Me-sag Archive (Maiocchi 2009; Maiocchi-Visicato 2012). There are some royal inscriptions which can be dated to the times of Sargon and his successors. ${ }^{4}$ Unfortunately, many of these sources are known only in later copies, which mainly date from the Old-Babylonian period (Frayne 1993, p. 7). ${ }^{5}$ Nevertheless, we are capable of drawing some conclusions, based on archaeological, historical as well as comparative research, concerning the economy and society of the Sargonic state. On the other hand, the lack of sources makes the possibilities of conceptualising any indubitable facts about the political history of the Akkadian Empire very limited.

Because of the contemporary state of research on Sargonic history, one could ascertain that there were no changes connected with the Sumero-Akkadian transition

${ }^{1}$ There are different ways of dating the reign of Sargon: 2334-2279 B.C. according to Frayne and ca. 2350 according to Westenholz (1997). Gurzadyan and Cole adapt the chronology of Gasche to the 3rd millennium, dating Sargon ca. 2250, while Sallaberger dates him at 2307-2253 or 2288-2234. See Frayne (1993, p. 7); Sallaberger (1999, p. 17; 2004, p. 42); Gurzadyan - Cole (1999); Gasche et al. (1998, pp. 42-45). According to the "long chronology" dates of Huber (using the astrological omina which concern eclipses), the first year of Sargon's reign was in 2380 or 2326 B.C., the Akkadian dynasty in the years 2381-2200 or 2327-2146. See Huber (1999/2000, p. 67).

${ }^{2}$ For the later history of Agade, see McEwan (1982).

${ }^{3}$ As for the contemporary state of knowledge, there are 8099 texts listed as Old Akkadian on the CDLI website with only 17 references to Ilaba, see in Cuneiform Digital Library Initiative $<$ www.cdli.ucla.edu $>$ [accessed 18 September 2013].

${ }^{4}$ For example, the obelisk of Maništusu, where there are some mentions of Ilaba. For instance, in column C (xiii:22) of this text the personal name Il-a-ba ${ }_{4}$-iš-da-gal is written. See Gelb et al. (1991, p. 135).

${ }^{5}$ Obviously, in lack of other sources of this kind, these copies should be accepted as valuable historical sources, all the more so since their composition seems to fit the Old Akkadian language of political discourse and propaganda. For more about the Old Babylonian copies of Old Akkadian inscriptions, see van de Mieroop (1999, pp. 62-63). 
during the reign of the Sargonic dynasty. Moreover, there are no visible signs of such a change in any remnants of the material culture (architecture, ceramics, writing system or handicraft), nor in the political state structure. ${ }^{6}$ Owing to this, there are many suggestions to focus the studies of the Old-Akkadian period on the political ideology which was changing visibly during Sargonic times. The most important role within the state was no longer played by the king-administrator, landlord and care-taker of the harmonious development of agriculture, but rather by a warrior king who focused on new victories and widening the area which was kept under his rule and supervision (Liverani 1993, pp. 4-8). ${ }^{7}$

\section{Historical Sketch of the Sargonic Dynasty}

The Sumerian King List (col. VI, v. 28-36) leaves us with only rudimentary information about Sargon and his origins:

"Uruk was smitten with weapons; its kingship to Akkade was carried. In Akkade Sargon - his father was a gardener - cupbearer of Ur-Zababa, king of Akkade, the one who built Akkade, became king. He reigned 56 years" (Jacobsen 1939b, p. 111; Glassner 1993, p. 141).

The image drawn above is made a little clearer thanks to later literary tradition, according to which Sargon of Akkade, founder of the new dynasty, reached power because of the mighty support of the goddess Ištar, in a coup d'état which took place during the reign of Ur-Zababa. This seizure of power was facilitated by the position of Sargon, who was Ur-Zababa's cupbearer. The problem emerges when one is trying to discover Sargon's origins. According to the "Sargon Legend", considered one of the quasi-biographical compositions, his ancestors lived in the mountains, and Sargon himself had never known his own father. He was deemed to have originated from the city of Azupirānu, arriving in Mesopotamia by flowing down the Euphrates in the little basket in which he had been placed by his mother - an entu priestess. ${ }^{9}$ From

${ }^{6}$ For example, changes in the palaeography of cuneiform writing took place only after Sargon's death, while the old sculpture style lasted until the reign of Maništusu. See Gibson-McMahon (1995, p. 5).

${ }^{7}$ For more details about the Akkadian dynasty and Mesopotamia in the times of Sargon of Akkade, see Jacobsen (1939a); Hallo (1963); Drews (1974); Grayson (1974-1977); Maeda (1981; 1984); Westenholz (1983); Franke (1995); Postgate (1994).

${ }^{8}$ In a manuscript of the Sumerian King List from the Ur III period 40 years are assigned to Sargon's reign: [Unug ${ }^{\mathrm{k}}$-ga ${ }^{\text {giš }}$ tukul ba-sàg nam-lugal-bi A-ga-dè ${ }^{\mathrm{ki}}$-šè ba-de 6 ] Sar-ru-gin ${ }_{7}$-né [A]-gadè ki $^{-a}$ mu 40 ì-na (USKL iv 13'-17'). See Steinkeller (2003, p. 272).

${ }^{9}$ CT 13 42:1-4: "Sargon, the mighty king, king of Akkade, am I. My mother was an enpriestess(?), my father I never knew. My father's brother inhabits the highlands. My city is Azupiranu, which lies on the bank of the Euphrates" (see Westenholz 1997, pp. 38-40). It must be underlined here that literary texts regarding Sargon's origins are mostly uninformative as historical sources, however interesting they are as literary topoi. 
another source, called the "Sumerian Sargon Legend", describing Sargon's way to power, his father was a man named Lā'ipu. ${ }^{10}$

Paradoxically, the time of Sargon's reign is even more difficult to reconstruct and to revise. Solely on the basis of historical sources, Old Babylonian copies of his inscriptions are preserved, some fragments of Sargonic royal inscriptions and four names of his reigning years, all known from Nippur, from the times following Sargon's conquest of this city (see Sallaberger 1999, p. 35) ${ }^{11}$ :

1. The Defeat of Uruk and the South

2. The Elamite Campaigns

- The year Sargon destroyed Arawa/The year Arawa was destroyed

- The year Sargon destroyed Elam

3. The Euphrates Campaign

- The year Mari was destroyed

4. The Simurrian Campaign

- The year Sargon went (on a campaign) to Simurrum

All reconstructions of Mesopotamian history during the reign of Sargon must be based on the above-mentioned sources, which leads to the necessity of the interpretation and confrontation of the historical texts with their literary counterparts. ${ }^{12}$ It must be mentioned that there are also omen texts including signs that invoke the achievements of Sargon as well as other rulers from his dynasty. The interpretations of such signs, being part of the magical-religious literature, can also be treated as hints or supplements to already known facts about this ruler. It might be seen as an irony of fate, but one of the features of the omina is the unchangeability of their causes as well as of the foreseen aftermaths. That is the main reason why the possibility to use them as historical sources cannot be excluded (see Finkelstein 1963, p. 463). ${ }^{13}$

Sargon's activity focused on a few main areas. First of all, he expanded the territory of his state by conquest. Furthermore, he greatly supported building activity and took care of the appropriate assets of the gods (e.g. temples). Conquests, constructions and maintanance of the temples were standard activities of all other rulers, but as far as the extent of these activities are concerned, Sargon's operations were matchless. It could be stated that no earlier ruler could boast of such extraordinary projects, military deeds and other activities. This is why Sargon became a legend in

${ }^{10}$ TRS 73 obv., 10'-11': "At that time Šarrumkēn, whose city is [...], whose father is Lā'ipum, and mother [...]" (see Afanas'eva 1987a, p. 238). See also electronic version of the same translation Sargon and Ur-Zababa at http://etcsl.orinst.ox.ac.uk/cgi-bin/etcsl.cgi?text=c.2.1.4\& display $=$ Crit\&charenc $=$ gcirc\&lineid $=\mathrm{c} 214$. A.10\#c214.A.10 [accessed 11 May 2015].

${ }_{11}^{11}$ Translation according to Frayne (1993, p. 8).

${ }^{12}$ In the subject of consideration the possibilities of reconstructing the chronology of the Akkadian dynasty, on the basis of existing sources, see Jacobsen (1927, pp. 302-309). Despite its age, the main conclusions of this paper are still up-to-date.

${ }^{13}$ According to Finkelstein, omina are the basics of Mesopotamian historiography. Ominous texts where Sargon is mentioned are listed in Hirsch (1963, pp. 7-9). For some notes about omina as historical sources, see Goetze (1947) and van de Mieroop (1999, p. 66). Sources for studying the history of the reign of Sargon are discussed in detail in Lewis (1980, pp. 125-148). The author dedicated one chapter to the omina, referring to Sargon on pp. 135-140. 
later times, and the memory of him and his reign lasted as long as those of Lugalbanda, Etana or Gilgameš (see Westenholz 1997, pp. 1-2 and Haul 2009, p. 232).

The conquests of Sargon and their range were an absolute novum in Mesopotamia. He was fighting throughout his whole reign, subordinating huge areas, from Eridu in the South to Hiza in the North, and from Kazallu in the West to Der in the East. If the Old Babylonian versions of Sargon's royal inscriptions are really reliable, being the exact copies of the earlier texts, we should accept the image of the ancient Blitzkrieg:

"Sargon, king of Akkade, bailiff of the goddess Aštar, king of the world, anointed priest of the god Anum, lord of the land, governor for the god Enlil, was victorious over Uruk in battle, conquered fifty governors with the mace of the god Ilaba, as well as the city (of Uruk), [and] destroyed its (Uruk's)] w[alls]. Further, he captured Lugal-zage-si, king of Uruk, in battle (and) led him off to the gate of the god Enlil in a neck stock. Sargon, king of Akkade, was victorious over Ur in battle, conquer[ed] the city and destroyed [its] w[alls]. [He conquered Eninmar], destroyed its walls, and conquered its district and Lagaš as far as the sea. He washed his weapons in the sea. He was victorious over Umma in battle, conquered the city, and destroy[ed] its walls. To S[argo]n, [lor]d of the [lan]d, to wh[om] [the god En]lil gave no r[ival], (the god Enlil) [gave] the Upper Sea and the Low[er] (Sea). [Further, from the Lower Sea to] the [Up]per [Se]a [citiz]ens of Akkade held the governorships (of the land). Mari and Elam stood (in obedience) before Sargon, lord of the land. Sargon, lord of the land, altered the two sites of Kiš. He made the two (parts of Kiš) occupy (one) city. As for the one who removes this inscription, may the gods Enlil and Šamaš tear out his foundations and destroy his progeny. As for anyone who sets aside this statue, may the god Enlil set aside his name and smash his weapon. May he not walk before the god Enlil.

Colophon Inscription on a socle; it is written in front of Lugal-zage-si" (RIME 2.1.1.2) ${ }^{14}$.

\section{Ilaba (il-a-ba 4$)$}

This inscription can serve as a basis for research on many interesting issues linked to the way how Sargon exercised his power and on how he treated the kings whom he had defeated. It can also help us investigate the royal political propaganda which constituted the integral part of the political ideology of the Akkadian dynasty. The interpretation of this source in this paper will be limited to the fragment concerning the role and importance of Ilaba - a god that was very often mentioned in the royal

\footnotetext{
${ }^{14}$ All RIME texts are cited according to Frayne (1993).
} 
inscriptions of the Sargonic period - in constructing the political and military power of the new state. In the above-cited text Ilaba emerges as the owner of the powerful mace, which was a tool that empowered defeating fifty rulers of other Mesopotamian cities, situated in the area between the Persian Gulf and the Ammanus mountains, with the Euphrates river as its centre. Some further details about Ilaba can be found in other fragments of Sargon's inscriptions. One of them includes information about the origins of Ilaba's mace, as well as the sources of this god's power:

"The god Ilaba, mighty one of the gods - the god Enlil gave to him (his) weapon(s)" (RIME 2.1.1.3, caption, v. 1'-6').

Above all, one should notice that Ilaba is described as the most powerful of the gods; such a designation is a little confusing as in Sargon's aforementioned inscription the gods Enlil and Utu are invoked in the cursing formula as the most powerful and important gods. It should be emphasised, too, that Ilaba was an unknown god in earlier times, at least in Mesopotamia, and his worship was established by Sargon. It was a novelty in the Mesopotamian area, typical of the Akkadian dynasty, since the cult of Ilaba emerged no earlier than the time of Sargon, and it vanished immediately after the Akkadian dynasty had faded away. Moreover, such a statement can be supported by textual sources, as before Sargon's reign there is no mention of Ilaba, not only regarding his worship, but his name is missing from toponyms or personal names as well, which are often the only source for studying non-Sumerian Mesopotamian cult and religion for that period (see e.g. Ebeling 1929, p. 91). ${ }^{15}$ What one can notice here is the unique, rapid career and enthronement of a hitherto unknown divinity who, without substituting any other traditional god, was considered the most powerful one. Therefore, it must have been taken into account in any form of worship.

On the other hand, one of the most important gods of the Mesopotamian pantheon, Enlil delegates his power and weapon to Ilaba (considered a god of war, and possibly a spouse of Ištar-Annūnitum, the goddess of Akkade) (Roberts 1972, pp. 148-149). The scene of Enlil giving his own battle weapon to Ilaba, pictured in the aforementioned source, could be regarded as an additional emphasis on his valour and power, made possible by the "father of gods". 16

${ }^{15}$ There is only one toponym, which can be connected with Ilaba, preserved on tablet ITT $1: 1096,2$. The toponym is written as $i_{7}$-da-ba-al-dingir-a-ba ${ }_{4}{ }^{k i}$, and read as I-Dabal-Aba in Edzard et al. (1977, p. 77). Nevertheless, it can also be read as I-Dabal-Ilaba. As far as I know, it is the only case of any toponym with the name of this deity. The personal names including the theonym "Ilaba" are mostly attested in Sargonic times, and they are as follows: Il-aba-ā̌š (Ilaba is his city), Il-abaandul (Ilaba is the protection), Il-aba-iš-takal (Trust in Ilaba), Il-il-aba (Ilaba is the god), Kašid-il$a b a$ (Ilaba has come), Rīssu-il-aba (Ilaba is his help). See also Roberts (1972, p. 34). The name of this god also appears in the personal names from Adab: Be-li-il-a-ba (Ilaba is my lord), the beginning of the second name is damaged and only the name Ilaba is preserved. Both aforementioned names are only attested in the Old Akkadian period, see Such-Gutierrez (2005/2006, p. 18). There are also some Ur III and Old Babylonian personal names which could be read Ilaba, see Kienast (1990, p. 203).

${ }^{16}$ It should be noted that although Enlil was considered to be the creator of humankind and the gods, one who gave people their first agricultural tool, the hoe, there are no mentions of the 
At this juncture an important question must be raised: how is it possible that in the royal inscription of the first known ruler of the new Akkadian dynasty there emerges a new, high-ranking divinity in the hierarchy? A probable explanation of this mystery can be found in another textual fragment in which a close relationship between Sargon and Ilaba is presented. The text reads as follows:

$$
\text { "Ilaba (is) his (personal) god" (RIME 2.1.1.3, w. 1-2). }{ }^{17}
$$

Because of this premise, the role and nature of Ilaba can be defined. So first the issue of the personal gods in the ancient Near East must be treated. The role of a personal god was played by different divinities, from those completely unknown to the well-known members of the official pantheon (see e.g. RIME 1.9.9.6, IV, 5-V, 9). ${ }^{18}$

A personal god, worshipped in many cultures in the ancient Near East, was very important in the daily life of ancient people. Such a god was the one who took care of his devotee(s), while his withdrawal from his tutelage was considered one of the main purposes of all the calamities experienced by humans. ${ }^{19}$ It seems likely that human contact with the tutelary deity was not just limited to the temporal existence in the world of the living. In one of the royal inscriptions of Rimuš, a son of Sargon, there is a plain threat against everyone who dares to destroy this engraving, commemorating the king's deeds. The punishment is cruel: a lack of possibility of standing in front of the personal god after one's death (RIME 2.1.2.4, 123-124; 2.1.2.6, 128130). ${ }^{20}$

Presumably, the cult of the tutelary/personal deity was inherited within a dynasty or even the whole kin. This conclusion can be based on the textual layer of the Mesopotamian royal inscriptions dated to the 3rd millennium B.C. A personal god of a father usually becomes the personal god of his son and other offspring, which testifies to the assumption that the factual role of a family divinity was that of a tutelary deity. ${ }^{21}$ Moreover, the cult of such a deity could even be adopted by the rulers who

weapon he possessed in the mythological texts. Therefore, one can assume that the mace (if it was the side-arms given to Ilaba) was a weapon attributed to Enlil only by the Akkadians.

${ }^{17}$ This name is sometimes wrongly read as Aba, see e.g. Kobayashi (1995, pp. 145-148).

18 "URU-KA-gina, king of Lagaš, who built the E-ninnu - may his personal god, Ninšubur, forever pray for his life to Ningirsu!"

${ }^{19}$ It is possible that further studies on the personal god could prove that such a deity was worshipped in every known culture of the Ancient Near East. Its existence has been proved so far in Mesopotamia, Anatolia, Arabia, Syria, Palestine and Israel. See Vorländer (1975); Dandamayev (1996, p. 45); Hyatt (1955, pp. 130-133). A common belief also existed that sorcerers and witches, if acted against people, tried to convince (by the mislead) one's personal deities to leave such a person alone. Such an opinion could be found, for instance, in one of the incantations recited during the maqlû ceremony, aimed at the effects of the evil spell cast against the innocent victim: "I summoned you, the gods of the night, I summoned with you together the night, a veiled bride. I summoned the dusk, midnight and dawn, because the witch bewitched me. The sorceress bound me. My god and my goddess she averted from me" (maqlû I: 4-6), see Meier (1937, p. 7). For more about the interdependence of the tutelary deity and the efficiency of spells, see Abusch (1999).

${ }^{20}$ Similarly in the Naram-Sîn's inscriptions: RIME 2.1.4.5, 14-16; 2.1.4.25, 68-70.

${ }^{21}$ This assumption can also be supported by the cylinder-seals inscriptions, see Hirsch (1966, p. 57); Charpin (1990, pp. 61-69); van der Toorn (1996, pp. 71-72). More "private" bonds between 
did not originate from the former dynasty. The latter probably used the deities of their predecessors to legitimise their own authority, which can be noted in the royal inscriptions of URU-KA-gina, lord of Lagaš, successor of Lugal-anda for instance (see RIME 1.9.9.9, 9'-17'). ${ }^{22}$

The name Ilaba was written in cuneiform script as DINGIR.A.MAL, which was the cause of some confusion and uncertainty in the proper reading for a long time. He was sometimes identified with Marduk or Zababa (see Ebeling 1929, p. 91), and his name was not adequately read until the discovery of Mesopotamian god lists (KAV 64 obv. iii 14, see Lambert 1981, p. 299, and NGL 5'-Peterson 2009, p. 16). Thanks to the proper reading (il-a-ba ${ }_{4}$ or DINGIR-a-ba ${ }_{4}$ ) new possibilities of interpretation were made available - the name of this god may be interpreted as including two parts - ilum (god) + abum (father) - and in such a case translated as "god, the father", "the god of father(s)" or "the god (is) the father". ${ }^{23}$ In such cases the name Ilaba could easily be linked with the ancestor cult. ${ }^{24}$ Moreover, in verse 37 of the 2 nd tablet of the bit mesēri ritual, a record DINGIR-a-bi seems to undoubtedly indicate the god of the father. Unfortunately, such an interpretation is not the only possible one, as this passage can also be translated as referring not only to the god of the father, but also to the father's spirit (Meier 1941-1944, p. 143). ${ }^{25}$

A history of the development of Ilaba's cult along with the growing strength of the Akkadian dynasty is absolutely intriguing. First and foremost, the worship of Ilaba was undoubtedly a matter of great importance for the whole clan. It can easily be noticed, especially in Naram-Sîn's inscriptions, since this king was one step ahead in

a ruler and his tutelary deity can also be evidenced, as in the case of Gudea and his personal god Ningišzida. See e.g. Woods (2004, p. 46).

${ }^{22}$ The reception of the previous dynasty's deity as one's personal god could have a political as well as a religious meaning of a continuation of the authority, power and rule of the predecessors.

${ }^{23}$ There are also other interpretations of this god's name. According to some of them it could be linked to Hittite $a-a-b i$, which means 'a pit dug in the ground', used for making offerings to the spirits of the dead and the inhabitants of the netherworld. Such an understanding leads straight to the possible connections with the Hebrew ' $o b$. There is also a possibility to bind this name with the Arabic la'aba, meaning 'place, set up', and can be referred to as the gravestone or stela, see Healey $(1999$, p. 447a). There is also an interpretation of the Ilib's name as "El is the father", especially with regard to Ugaritic sources, see Tropper (1989, p. 131). There are some proposals to read ${ }^{\mathrm{d}} \mathrm{Aba}$ instead of Ilaba, esp. Kienast (1990). Nevertheless, in the light of recently published MSL, such names contains Ilaba. Moreover AN.GÁ should be read Ilaba, too. For this see Civil (2004, p. 36).

${ }^{24}$ The suggestions that the dead ancestors were described as gods, without any special distinction from the deities of the official pantheon, are also reasonable (see de Moor 1997, p. 330). Nevertheless, it seems likely that de Moor's suggestion (p. 331) that supposedly Ilu was considered the archetypical ancestor and therefore every father's spirit was Ilu's manifestation, is an oversimplification.

${ }^{25}$ It should be noted that this fragment does not concern the tutelary deity, but rather the deified ancestor (see van der Toorn 1993, p. 382). Additional proof of the deification of the ancestors could be the Old Assyrian personal names like A-bi-li (My father (is) my god) or Abu-um-AN-lum (The father is the god) (see Hirsch 1961, p. 40). 
the means of royal propaganda, and he even deified himself. ${ }^{26}$ His name was from this time on written with the divine determinative, and officially the lands of Sumer and Akkad were being governed by a new god - Naram-Sîn. With the changed status of the king, the king's tutelary deity was also changed from Ilaba to Enlil. Nevertheless, it was not a case of reducing the rank of Ilaba, as he was "promoted" to the rank of the tutelary deity of the whole clan. ${ }^{27}$

The above-mentioned ruler established the cult of Ilaba among all his subordinates. One of his royal inscriptions, where the military deeds of the king are described, reads as follows:

"Further, from the side of the Euphrates River as far as (the city of) Ulišum, he smote the people whom the god Dagan had given to him for the first time, so that they perform service for the god Ilaba, his god" (RIME 2.1.4.26. col. II, 8-23).

It should be noted that it was Ilaba, the tutelary deity of the victorious king's clan, who had to be worshipped by the inhabitants of the conquered area. One would have rather expected the establishment of the cults of the principal Mesopotamian gods, or, at least, the restoration of the cult of the main god of the subjugated country in this case Dagan. Could this political decision be justified by the pursuit of increasing the role of Ilaba until his assimilation with the official pantheon? Such an idea can be supported by another example from textual sources. The name of one of the years from the reign of Šar-kali-šarri, the last representative of the Akkadian dynasty, refers to his building activity - the construction of a temple of Ilaba, the last step on the long way of this god to becoming part of the official pantheon. This event took place in the third year of the reign of Sar-kali-šarri, and the description reads as follows:

"The year, when Šarkališarri laid the foundation of the temple of Annunitum and the temple of Ilaba in Babylon, and caught Sarlag, the king of Gutium". 28

${ }^{26}$ According to textual evidence, Naram-Sîn was not the first deified Akkadian king, but the first who was deified alive (and by himself). There existed a cult of Sargon of Akkade, established presumably by his followers, which is proved in textual sources from the Ur III (CT 7, pl. 25, No. 13164) and even Late Babylonian Period (see Hirsch 1963, p. 5). This also seems to be the rule in the case of Rimuš and Maništusu (see Hirsch 1963, p. 13 and 16 respectively). Such a tradition can additionally prove the "customary" ancestor's deification as the source of the cult of Ilaba, god of the father.

${ }^{27}$ RIME 2.1.4.6. col. I, 1-5: "The god Enlil (is) his (personal) deity (and) the god Ilaba, mighty one of the gods, is his clan (god)". The transition in the way Ilaba was perceived is apparent. As long as he was called "personal god", there was no need for any additional explanation of his role among the Sargonic family. As Naram-Sîn changed his divine patron purposely, it became essential to underline the position of Ilaba as the god of the clan and guardian of family members. The thesis, according to which the personal god must have been different from the family god, claimed by van der Toorn (1996, p. 156) cannot be applied to the early forms of religious development.

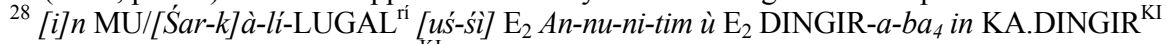
$i s ́-k u$-nu ù ${ }^{m}$ Sar-la-ag LUGAL Gus-ti-im ${ }^{\mathrm{KI}} i k$-mi-ù (Gelb-Kienast 1990, pp. 54, D-27). 
At this point, a summary of Ilaba's short history should be given, beginning with the first year of the reign of Sargon. At a vague point in Sargon's rule, which is hard to pin down, the personal/tutelary deity was introduced into the pantheon. As there are some inscriptions describing the victories of Sargon over the Sumerian cities, the assumption that such an introduction took place no later than fifty years after his seizure of power can be made. ${ }^{29}$ After self-deification, one of the later Akkadian rulers begins (or strengthens) the policy of widening the worship of his kin-god, which is reflected in the aforementioned inscription, concerning the conquest of Armānum. Therefore, the period between the emergence of Ilaba in the royal inscriptions and a new religious policy must be no shorter than twenty-seven years. ${ }^{30}$ Forty years later, before the successive activities aimed to well-establish the worship of Ilaba, the construction of this god's temple is mentioned in the royal annals. ${ }^{31}$ In other words, from the first mention of Ilaba to the establishment of his official cult there were at least sixty-seven but no more than one hundred and seventeen years, and, what is even more important, the whole process ended within four generations - the temple of Ilaba was built by the great grandson of Sargon. From one point of view this was an attempt to adapt the kin-cult to the Sumerian religious conditions, while from another it is an exaltation of the family god to an official rank. The long duration of the Akkadian dynasty could account for the proclamation of Ilaba as the chief god in the Mesopotamian pantheon, but this must remain hypothetical.

Nonetheless, the question of the limitation of the cult of Ilaba solely to the Sargonic family must be considered. The first proof from another area, of the existence of this god in worship, was found almost a millennium later in textual sources from Ugarit. In the divine list KTU 1.47:2 and KTU 1.118:1 there is mention of a god whose name is based on the same consonantal root - ' 1 'b. Such a root can be vocalised as Ilib, for example, or 'Ilu'ibī (see Pardee 2002, p. 280). ${ }^{32}$ The position of Ilib in these texts, organised according to the hierarchy of gods, speaks of its great importance, as the list begins with Ilib, followed by El, Dagan and Baal. ${ }^{33}$ If such lists were composed by ancient authors on the basis of the position of the gods in the pantheon and such a position depended on the affiliation to the next generation within the great

${ }^{29}$ According to the length of his reign, as stated in the Sumerian King List (see Jacobsen 1939b, p. 111; Glassner 1993, p. 141 and Sallaberger 2004, p. 42).

${ }^{30}$ On the assumption that the incorporation of the South took place 4 to 5 years before Sargon's death, the reign of Rimuš lasted seven, and Maništusu fifteen years (see Sallaberger 2004, p. 42).

${ }^{31}$ On the assumption that Naram-Sîn reigned for 37 years, see Sallaberger $(1999$, p. 47; 2004, p. 42).

${ }^{32}$ Contrary to his opinion that this god was "apparently referring to the ancestral head of 'Ilu's family and hence of all the gods", I strongly suggest that the origin of this name is exactly expressed by its meaning - "the god of the father" - with "father" referring not to any deity, but to human ancestors. Note that Pardee also translates the name of this deity as "The God-of-the-Father" instead of "The Father-of-the-God" (Pardee 2002, p. 16).

${ }^{33}$ There are also some other Ugaritic sources, where this god is mentioned at the head of the list, indexed in Pardee (2002, p. 288). On the position of gods in such god-lists, see Xella (1995, p. 2062). Similarly to Mesopotamian texts where Ilaba is mentioned (UET 773 i 11-12; MAH 10829:21 - 22 [published by Waldemar Deonna in Genava 17 (1939), 028 No. 2]; VAS 17 42:1-2). See also Westenholz (1992, p. 139). Regarding Mesopotamian god-lists, see Litke (1998). 
family of gods ${ }^{34}$, then Ilib could be put at the head of such a list as the oldest, maybe even as the primeval god, the ancestor of other deities (see van der Toorn 1996, p. 158 and Healey 1999, p. 447a). ${ }^{35}$ It may be questioned, if Ilib, just like Hurrian Alalu, is not simply a personification of all divine beings who were worshipped in the earliest times and who had then fallen into oblivion (van der Toorn 1993, p. 385). Nevertheless, such a viewpoint seems insufficient to account for the vitality of the cult of Ilib/Ilaba, which lasted for no less than a thousand years.

The royal archives of Mari, dated to 1900 B.C., provide more proof of the existence of Ilaba's cult outside Mesopotamia whilst filling a thousand-year gap between the Old Akkadian and the Ugaritic sources. The name of the Sargonic god appears there in some personal names. There can be distinguished, for instance, Anail-aba-taklāku (I trust in Ilaba), Idin-il-aba (Ilaba judged correctly), Puzur-il-aba (under the protection of Ilaba), Qīsti-il-aba (my gift of Ilaba) (Birot et al. 1979, p. 263). ${ }^{36}$

A third argument is based on the royal inscriptions of the rulers of the land of Hana, which was simultaneously under the influence of Mari as well as of the Babylonian kings. The history of its existence, however short, refers to a period between 1750 and 1200 B.C. and includes the rule of nineteen or twenty-one kings (Gelb 1961, p. 36; Podany 2002, pp. 10-11). ${ }^{37}$ If the scarce textual sources were enough to help us form any opinion, it would seem probable that Ilaba played a very important role in the life of royal families. The readable data are preserved in the royal titles written in the seal impressions in the mercantile documents. For example, the king Išar-Līm is introduced in such a text as follows:

"Išar-Līm, king of the land of Han[a], son of Iddin-Kakk[a], beloved of the gods Il[a]b[a], and D[a]gān" (AO 2673 = GC1 1. See Podany 2002, p. 124 and Frayne 1990, p. 730).

In the seal impression of his successor (maybe his son), the dependent state of the king in relation to Ilaba is expressed as follows:

"[Iggid-Lìm, g]overnor of the god [Dag]ān, [k]ing of the land of Hana, [s]on of Išar-[L]īm, [se]rvant [of the gods Ilaba and] Da[gān]" (TPR 7, no. 4; RBC 779. See Podany 2002, p. 128 and Frayne 1990, p. 731).

The above text is repeated literally in the seal impression of the Iggid-Lim's son, Isih-Dagan:

"Isih-Dagan, governor of the god Dagan, [king of the land of $\mathrm{H}$ ] an[a], son of Iggid-L[īm], servant of the gods Ila[ba] and Dag[ān]” (AO 20162

= GC1 19. See Podany 2002, p. 131 and Frayne 1990, p. 732).

${ }^{34}$ It must be stressed that such a way of composing these lists still remains hypothetical.

${ }^{35}$ The above-mentioned lists are compared by Toorn with an identically composed Hurrian god-list, found in Ras Šamra, who properly notes that the position of the god in the hierarchy depends on its seniority.

${ }^{36}$ For the way of translation of names, see especially Stamm (1939).

${ }^{37}$ Some notes about the worship of Ilaba are attested in the sources from Mari and Hana, see also Frayne (1992, p. 629). 
The last ruler of the land of Hana, by whom Ilaba was invoked in the royal titles, is Hammu-rāpi, who reigned ca. 1400 B.C. His inscription differs from the texts cited above since the king is described not only as a servant of both gods, but also as a governor of Ilaba and Dagan. With these expressions a promotion of Ilaba within the royal gods' hierarchy is pointed out:

"[H]ammu-r[āpi], governor of the gods Dagan, and Il-aba, king of the land of Hana, [son of] Ag[i-,..], servant of the gods II-[aba], and D[agān]" $($ MLC $613=$ GC1 2. See Podany 2002, p. 135 and Frayne 1990, p. 733).

On the basis of the comparison discussed above, the chronology of the worship of Ilaba, as mentioned in textual sources, seems to look as follows:

- ca. 2350-2200 - Old Akkadian Mesopotamia

- ca. 1900 - Mari

- ca. 1750-1400 - Hana

- after 1400 - Ugarit.

By virtue of an additional and careful look at another source it could be noticed that "god of father" or "god of fathers" was venerated and had an established position in the entire ancient Near Eastern religious tradition, or at least in its Semitic cultural circle. In the Old Assyrian sources from the karum Kaneš (Kültepe) there are mentioned oath formulae where "my/your god" or "god of the father(s)" is included, and where the god played the role of a guardian of the oath or testimony (BIN 6, 39:18; BIN 6, 97:20; BIN 6, 119:11-12, 30; CCT 3, 20:40; KTS 15: 24; TC 3, 46:10; CCT 4, 14b:8; CCT 3, 16b:5-6; see also Hirsch 1961, pp. 13-16 and Vorländer 1975, pp. 12-13). In the Old Testament, God is often described as the "god of the father(s)". This epithet is used in the fragments referred to in the history of the Patriarchs as well as in the loci concerning the history of Israel after the departure from Egypt. For instance, Jacob, being accused by Laban's son of the dishonest enrichment, spoke to Leah and Rachel as follows:

"And Jacob sent and called Rachel and Leah to the field unto his flock, and said unto them: 'I see your father's countenance, that it is not toward me as beforetime; but the God of my father hath been with me" (Gen $31: 4-5)^{38}$

When Jacob, together with his wives and possessions, left in secret a house belonging to his father-in-law, Laban follows and intercepts him. During their meeting the latter reveals that the god of Jacob had ordered him not to mistreat Jacob:

"It is in the power of my hand to do you hurt; but the God of your father spoke unto me yesternight, saying: Take heed to thyself that thou speak not to Jacob either good or bad" (Gen 31:29).

Jacob, angry with Laban, who accused him of theft, blames him:

${ }^{38}$ All Biblical citations follow the on-line translation "The Official King James Bible Online" at http://www.kingjamesbibleonline.org/. 
"Except the God of my father, the God of Abraham, and the Fear of Isaac, had been on my side, surely now hadst thou sent me away empty. God hath seen mine affliction and the labour of my hands, and gave judgment yesternight" (Gen 31:42).

Next time the "god of the father" is mentioned in the story of Joseph. His brothers, after having discovered in their sacks of grain the same gold with which they had previously paid for this very grain, came back to Egypt to explain that it had been done without their knowledge. The house master of Joseph answered them as follows:

"And he said: 'Peace be to you, fear not; your God, and the God of your father, hath given you treasure in your sacks; I had your money" (Gen. $43: 23)$.

Another fragment referring to the "god of the father" can again be found in the story of Jacob. God spoke to him as follows in a vision which he had in a dream:

"And He said: 'I am God, the God of thy father; fear not to go down into Egypt; for I will there make of thee a great nation. I will go down with thee into Egypt; and I will also surely bring thee up again; and Joseph shall put his hand upon thine eyes" (Gen. 46:3-4).

As can clearly be seen in the stories of the Patriarchs, their god is described as the "god of the father". Such an epithet will be repeated in the story of Moses who, as chosen by God to be the liberator of the whole nation from Egyptian slavery, experienced the will of God thanks to the revelation in the burning bush. In order to identify Himself properly, God speaks to Moses as follows:

"I am the God of thy father, the God of Abraham, the God of Isaac, and the God of Jacob" (Exod. 3:6).

Striking in this example is the way in which God introduces himself to Moses not only as the god of Patriarchs, but also as the god of Moses's father. It may be suggested that the "god of father" was much closer, more important and better specified (emotionally) to Moses than any vague deities of his (not direct) predecessors. From another point of view, because of such a rhetorical construction, the tutelary god (the god of the father) could easily be identified by Moses (or any other addressee) with the God of Patriarchs, which implies and manifests the continuity of the religious tradition. $^{39}$

The worship of the "god of the father" was deeply rooted in ancient Israel, and this can be proven by the fact that Joshua appealed to this deity when solving a stalemate caused by seven tribes of Israel that did not choose the land for their settlement. To strengthen his argument, Joshua admonishes the tribal officials as follows:

${ }^{39}$ It should be added that the name of the god revealed to Moses - YHWH - usually translated as "I am, who I am", might also be interpreted as "I am, who grants existence" (according to E. Lipiński ("Religiology and Philology", unpublished), and thus perfectly fits the ancestor who caused the existence of his offspring. 
"How long are ye slack to go in to possess the land, which the LORD, the God of your fathers, hath given you?" (Josh. 18:3).

Although this matter is not the direct topic of this paper, a few comments and remarks on the theory of the "god of the father" seem reasonable. A detailed study that opened up the discussion of the "god of the father" in the Bible and Israelite religion was written by Albrecht Alt (Alt 1929). His study was focused on the Bible and its cultural background, mostly from the eastern part of Syro-Palestine. Two of the most important claims of his study are that (1) the worship of the god of the father is the root of the cult of Jahwe and (2) that such a form of religion is typical of the nomadic societies (Alt 1929, pp. 48-49). Despite its rather outdated evolutionary profile (Alt 1929, esp. pp. 68-77) and the heated debate that followed his book (see e.g. Lewy 1934), Alt's theory was accepted in the main by most scholars, especially as far as his identification of the "god of the father" with the "god of the clan" is concerned (e.g. Nikiprovetzky 1975, p. 79). Also, the connection of such a god with the group of people and not with a particular place is largely accepted (Levine 2007). Nonetheless, a few comments and improvements of this model ought to be presented here. Firstly, Alt presumed that the religion of Ancient Israel was a unique phenomenon; so no other "gods of NN" can be compared with it. Such a theory can easily be rejected as was argued by Vorländer (1975, pp. 3-4, 206-208). In addition, on p. 211 he also rejected Alt's theory about the nomadic roots of the worship of a personal god. I would warn to hastily accept Vorländer's concept. Although in sedentary societies such a cult also existed, it would be a proof ex nihilo for the non-nomadic origins of the personal god. This negation could be contrasted with the fact that the survival of a sedentary society usually depends on agriculture, and that is why divinities connected directly with nature are the most important ones. Thus, the origins of the "urban" version of religion are very hard to trace and no solution to this problem can so easily be negated. What is unacceptable and must be rejected is Alt's intentional omission of the "el deities" which he considered unimportant as local and tied to shrines in Kanaan. ${ }^{40}$ Alt also did not consider the "god of the father" as the deified ancestor, claiming that this was the deity which revealed itself to the first worshipper (Alt 1929, p. 49). Such a statement is evidently untenable in the light of textual data. A further detailed treatment of the numerous publications in which Alt's proposals are discussed has no point in elucidating the topic of this paper.

The above compilation of selected textual sources clearly displays that the worship of deified ancestors was very widespread in the ancient Near East (Healey 1999, p. 448a). ${ }^{41}$ Such a cult is often mentioned in the extant textual sources written by authors of the Semitic peoples, in the descriptions of rituals, traditions, formulas or personal names. From the Zagros Mountains in the East to the Mediterranean Sea, over at least one millennium the "god of the father(s)" played a very important role

${ }^{40}$ See the detailed critics of Alt's postulations, with many references in Cross (1962, pp. 225-232).

${ }^{41}$ Such a god is also attested in the Ebla texts, regarding sacrifices for the god of the father [dingir a-mu-(sù)]. For more details, see Pomponio-Xella (1997, p. 233). 
in private family worship. It was so important that under favourable circumstances attempts were made to establish an official, state cult of such a god, like during the Old Akkadian period in Mesopotamia. There must of course have been some special conditions under which such an idea could grow freely and whereby the official cult of the "god of the father(s)" could be born and developed. In light of the above-cited sources, it seems unlikely that the Biblical "god of the fathers" is different from the other divinities worshipped under the same name or apprehended in the same way in other societies of the ancient Near East. ${ }^{42}$

On the basis of the history of Israel and its God, left by the Biblical editors and confronted with the Sargonic inscriptions, it is possible to make a proposal concerning the development of the official cult in general. The history of the Biblical "god of the father" is very similar to the story of the Akkadian Ilaba. A new god was introduced into the Hebrew religious system, a god who equated all the family and personal tutelary deities, who was worshipped by the members of the whole society. ${ }^{43}$ Such a deity, as it could not be declared as the principal god in the pantheon (which did not exist), was proclaimed the most important one among the previous deities; and being equated with the earlier deified ancestors, it was accepted and recognised as the only one. As a consequence, a new cult was born: the one god was worshipped by the whole society, and the only place for the only god was dedicated, the Tent of Meeting. The final point of this process was creating a Temple, built in Jerusalem after the political stabilisation of the kingship, which, according to the Biblical tradition, was erected during the reign of Salomon.

\section{Conclusion}

The above considerations are based on the expression "god of the father(s)", mentioned in textual sources from the whole area of the Fertile Crescent inhabited by Semites between the third and first millennium B.C. Moreover, as in the case of the earliest attested passus concerning Ilaba, the presence of such a god can be traced

${ }^{42}$ On the theory about such a difference see Alt (1929, p. 31); Cazelles (1989, p. 59); Lambert (1981, p. 299); van der Toorn (1993, p. 380). For constructive criticism of Alt's assumptions, see Vorländer (1975, pp. 206-214). According to Toorn, the official cult of YHWH in ancient Israel is rooted in the Edomite origins of Saul (see van der Toorn 1996, p. 286). It seems to be a very dubious conjecture, as one question must be raised: could Saul establish a cult of an unknown and new deity at once at the state level, if fifteen hundred years earlier it had taken the ruling dynasty of Akkade no less than four generations?

${ }^{43}$ It must be clearly stated that the expression "religious system" is used here to describe the entirety of the unspecified cults and worships that were present among (proto-)Israelites in the pre-Moses times. There is no suggestion of the existence of any pantheon or even a worship in the community of the tribes that later built the Israel society. The inexistence of any such "system" is equiprobable, as every family could simply worship its own tutelary deity. In such a case, despite the cult of many gods, their number in the newly created nation would be apparent, and the religiousness closed within every kin, which could obstruct, or even disable, the establishment of the coherent religious system among the society. 
back a thousand years under the same name, but in different regions of the ancient Near East. From Sumer in the South to Mari and Ugarit in the North, Ilaba played a very important role in the royal inscriptions, as well as in the theological sources, the the divine-lists. In the latter, he was placed in an honourable, principal position, being mentioned before the main gods of the local pantheons.

The observations made while studying the phenomenon of Ilaba and the vitality of his cult could serve as the basis for the statement that the god of the fathers - aside from assumptions of the tutelary deity as a god of ancestors or a god who is a deified ancestor - seems to be situated in the centre and at the very core of the religious life among the Semitic peoples that lived in the ancient Near East. This can be supported by the clear aspirations of rulers to emphasise the role of Ilaba in private and official life, which led to widening and strengthening his position and worship in the state. These rulers did not successfully complete the activities which they undertook, perhaps because of strong Sumerian and agricultural polytheistic traditions in the social environment. In light of the state of preservation of extant textual sources, the question about the possible development of the cult of Ilaba until the permanent change in the Mesopotamian pantheon, with Ilaba as the principal god (in the case of a longer reign of the Akkadian dynasty), must remain unanswered. It is also uncertain whether the development of the Israelite religion may be treated as similar or parallel to the evolution of the cult of Ilaba.

Moreover, one could ask whether the cult of Ilaba had spread from Mesopotamia to the other areas of the ancient Near East. In favour of such a suggestion, the chronology of textual sources, where Ilaba is mentioned, may be quoted (see p. 74). In such a case, a reconstruction of the route of the victorious march of Ilaba as the tutelary deity of kings would be very simple indeed: it would have begun in the capital of Sargon's state, embracing all the areas along the Euphrates, as well as the territories which were on the west side of the Balih river, finishing in the area of ancient Ugarit. Nevertheless, if such a reconstruction could be made, it must be remembered that Sargon of Akkade was not a member of the local society, the Sumerian community, but he was the representative of a new, Semitic group which was part of the immigrant population of southern Mesopotamia. In view of this, another hypothesis can be put forward, namely, that the cult of Ilaba, an ancestral deity, was typical of the Semitic cultural circle reaching Mesopotamia with a population of Semitic origins (Akkadians). In such a case, the above-reconstructed route of the cult would have to be inverted: it is possible that Ilaba is mentioned in the textual sources from the areas of the middle and upper Euphrates, because this is the cradle of the worship of the ancestral god, the tutelary deity of the ruling family. It is also possible that the oldest sources concerning the personal god come from southern Mesopotamia only because of the earlier writing tradition and not because of the religious tradition in this area. If this thesis would prove correct, then Sargon's origins could be indicated by the traces of the cult of Ilaba. 


\section{References}

Abusch, T. (1999): Witchcraft and the Anger of Personal God. In: Abusch, T. - van der Toorn, K. (ed.): Mesopotamian Magic. Textual, Historical and Interpretative Perspectives. Groningen, Styx, pp. 81-122.

Afanas'eva, V. (1987a): Das Sumerische Sargon-Epos. Versuch einer Interpretation. Altorientalische Forschungen Vol. 14, pp. 237-246.

Afanas'eva, V. (1987b): Sargon and Ur-Zababa. [Online] Available at: HYPERLINK http://etcsl. orinst.ox.ac.uk/cgibin/etcsl.cgi?text $=\mathrm{c} .2 .1 .4 \&$ display $=$ Crit\&charenc $=$ gcirc\&lineid $=\mathrm{c} 214$. A. 10" $\backslash 1$ "c214.A.10 [Accessed 11 May 2015].

Alt, A. (1929): Der Gott der Väter. Stuttgart, Kohlhammer (Beiträge zur Wissenschaft vom Alten und Neuen Testament 12).

Birot, M. - Kupper, J. R. - Rouault, O. (1979): Répertoire Analytique. Noms Propres. Paris, Libraire Orientaliste Paul Geuthner (Archives Royales de Mari XVI/1).

Cazelles, H. (1989): Der persönliche Gott Abrahams und der Gott des Volkes Israel. In: Mossis, R.Ruppert, L. (eds): Der Weg zum Menschen. Festschrift A. Deissler. Freiburg-Basel-Wien, pp. 46-61.

Charpin, D. (1990): Les divinités familiales des Babyloniens d'après les légendes de leurs sceauxcylindres. In: Özguc, T. (ed.): De la Babylonie à la Syrie en passant par Mari. Mélanges offerts à Monsieur J.-R. Kupper à l'occasion de son 70te anniversaire. Liège, Universitè de Liège, pp. 59-78.

Civil, M. (ed.) (2004): The Series DIRI = (w)atru. Rome, Pontificium Institutum Biblicum (Materials for the Sumerian Lexicon 15).

Cross, F. M. J. (1962): Yahweh and the God of the Patriarchs. The Harvard Theological Review Vol. 55, No. 4, pp. 225-259.

Dandamayev, M. (1996): State Gods and Private Religion in the Near East in the First Millennium B. C. E. In: Berlin, A. (ed.): Religion and Politics in the Ancient Near East. Bethesda, pp. $35-46$.

de Moor, J. C. (1997): The Rise of Yahwism. The Roots of Israelite Monotheism. 2nd ed. Leuven, Leuven University Press (Bibliotheca Ephemeridum Theologicarum Lovaniensium XCI).

Drews, R. (1974): Sargon, Cyrus and Mesopotamian Folk History. Journal of Near Eastern Studies Vol. 33, No. 4, pp. 387-393.

Ebeling, E. (1929): A.MAL. In: Erich, E.-Bruno, M. (eds): Reallexikon der Assyriologie. BerlinLeipzig, Walter de Gruyter \& Co., p. 91.

Edzard, O. D. - Farber, G. - Sollberger, E. (1977): Die Orts- und Gewässernamen der präsargonischen und sargonischen Zeit. Wiesbaden, L. Reichert.

Finkelstein, J. J. (1963): Mesopotamian Historiography. Proceedings of the American Philosophical Society Vol. 107, No. 6, pp. 461-472.

Foster, B. R. (1982): An Agricultural Archive from Sargonic Akkad. Acta Sumerologica Vol. 4, pp. $7-51$.

Franke, S. (1995): Kings of Akkad: Sargon and Naram-Sin. In: Sasson, M. J. - Baines, J. - Beckman, G.-Rubinson, K. (eds): Civilizations of the Ancient Near East. New York, Charles Scribner's Sons, pp. 831-842.

Frayne, D. R. (1990): Old Babylonian Period (2003-1595 BC). Toronto, University of Toronto Press (The Royal Inscriptions of Mesopotamia. Early Periods 4).

Frayne, D. R. (1992): The Old Akkadian Royal Inscriptions: Notes on a New Edition. Journal of the American Oriental Society Vol. 112, No. 4, pp. 619-638. 
Frayne, D. R. (1993): Sargonic and Gutian Periods. Toronto, Toronto University Press (Royal Inscriptions of Mesopotamia Early Periods 2).

Gasche, H. - Armstrong, J. A. - Cole, S. W. - Gurzadyan, V. G (eds) (1998): Dating the Fall of Babylon. A Reappraisal of Second-Millenium Chronology. Ghent-Chicago, University of Ghent and the Oriental Institute of the University of Chicago (Mesopotamian History and Environment 4).

Gelb, I. J. (1952): Sargonic Texts from the Diyala Region. Chicago, Chicago University Press (Materials for the Assyrian Dictionary 1).

Gelb, J. I. (1961): The Early History of the West Semitic Peoples. Journal of Cuneiform Studies Vol. 15, No. 1, pp. 27-47.

Gelb, J. I. - Kienast, B. (1990): Die Altakkadischen Königsinschriften des dritten Jahrtausends v. Chr. Stuttgart, Franz Steiner Verlag (Freiburger Altorientalische Studien 7).

Gelb, I. J. - Steinkeller, P. - Whiting, R. M. (1991): Earliest Land Tenure Systems in the Near East: Ancient Kudurrus. Chicago, The Oriental Institute of the University of Chicago (Oriental Institute Publications 104).

Gibson, M. - McMahon, A. (1995): Investigation of the Early Dynastic-Akkadian Transition: Report of the 18th and 19th Seasons of Excavation in Area WF, Nippur. Iraq Vol. 57, pp. 1-39.

Glassner, J.-J. (1993): Chroniques mésopotamiennes. Paris, Les Belles Lettres.

Goetze, A. (1947): Historical Allusions in Old Babylonian Omen Texts. Journal of Cuneiform Studies Vol. 1, pp. 253-265.

Grayson, A. K. (1974-1977): The Empire of Sargon of Akkad. Archiv für Orientforschung Vol. 25 , pp. $56-64$.

Gurzadyan, V. G. - Cole, S. W. (1999): Ur III Eclipses Revisited. Akkadica Vol. 113, pp. 1-15.

Hallo, W. W. (1963): Early Mesopotamian Royal Titles: A Philologic and Historical Analysis (American Oriental Series 43). 2nd edition. New Haven, American Oriental Society.

Haul, M. (2009): Stele und Legende. Untersuchungen zu den keilschriftlichen Erzählwerken über die Könige von Akkade. Göttingen, Universitätsverlag Göttingen (Göttinger Beiträge zum Alten Orient 4).

Healey, F. J. (1999): Ilib. In: Becking, B. - van der Toorn, K. - van der Horst, P. W. (eds): Dictionary of Deities and Demons in the Bible. 2nd ed. Leiden-Boston-Köln, Brill, pp. 447-448.

Hirsch, H. (1961): Untersuchungen zur altassyrischen Religion. Graz (Archiv für Orientforschung, Beiheft 13/14).

Hirsch, H. (1963): Die Inschriften der Könige von Agade. Archiv für Orientforschung Vol. 20, pp. $1-82$.

Hirsch, H. (1966): Gott der Väter. Archiv für Orientforschung Vol. 21, pp. 56-58.

Huber (1999/2000): Astronomical Dating of Ur III and Akkad. Archiv für Orientforschung Vols 46/47, pp. 50-79.

Hyatt, P. J. (1955): Yahweh as "The God of My Father". Vetus Testamentum Vol. 5, No. 2, pp. $130-133$.

Jacobsen, T. (1927): On the Chronology of the Agade Dynasty. Acta Orientalia Danensia Vol. 5, pp. $302-309$.

Jacobsen, T. (1939a): The Assumed Conflict between Sumerians and Semites in Early Mesopotamian History. Acta Orientalia Danensia Vol. 59, No. 4, pp. 485-495.

Jacobsen, T. (1939b): The Sumerian King List. Chicago, The University of Chicago Press (Assyriological Studies 11).

Kienast, B. (1990): Narāmsîn mut dInanna. Orientalia Nova Series Vol. 59, pp. 196-203.

Kobayashi, T. (1995): Ninazu, the Personal Deity of Gudea. Orient Vols 30-31, pp. 142-157.

Kuhrt, A. (2000): The Ancient Near East c. 3000-330 BC. London, Routledge. 
Lambert, W. G. (1981): Old Akkadian Ilaba = Ugaritic Ilib? Ugarit Forschungen Vol. 13, pp. 299301.

Levine, C. (2007): The Yahwist: The Earliest Editor in the Pentateuch. Journal of Biblical Literature Vol. 126, No. 2, pp. 209-230.

Lewis, B. (1980): The Sargon Legend: A Study of the Akkadian Text and the Tale of the Hero Who Was Exposed at Birth. Cambridge, American Schools of Oriental Research.

Lewy, J. (1934): Les textes paléo-assyriens et l'Ancien Testament. Revue de l'histoire des religions Vol. 110, pp. 29-65.

Litke, R. R. (1998): A Reconstruction of the Assyro-Babylonian God-Lists, AN:dA-NU-UM and $A N: A N U \check{S} A_{2} A M E L I$. New Haven, Yale Babylonian Collection (Texts from the Babylonian Collection).

Liverani, M. (1993): Akkad: An Introduction. In: Liverani, M. (ed.): Akkad: The First World Empire. Structure, Ideology, Traditions. Padova, Sargon (History of the Ancient Near East/Studies 5), pp. $1-10$.

Maeda, T. (1981): "King of Kish" in Pre-Sargonic Sumer. Orient Vol. 17, pp. 1-17.

Maeda, T. (1984): "King of the Four Regions" in the Dynasty of Akkade. Orient Vol. 20, pp. 6782.

Maiocchi, M. (2009): Classical Sargonic Tablets Chiefly from Adab in the Cornell University Collections. Bethesda, Maryland, Cuneiform Digital Library Press (Cornell University Studies in Assyriology and Sumerology 13).

Maiocchi, M.-Visicato, G. (2012): Classical Sargonic Tablets Chiefly from Adab in the Cornell University Collections. Part II. Bethesda, Maryland, Cuneiform Digital Library Press (Cornell University Studies in Assyriology and Sumerology 19).

McEwan, G. J. P. (1982): Agade after the Gutian Destruction: the Afterlife of a Mesopotamian City. In: Hirsch, H. (ed.): Vorträge gehalten auf der 28. Rencontre Assyriologique Internationale in Wien, 6.-10. Juli 1981. Wien, Verlag Ferdinand Berger \& Söhne GMBH (Archiv für Orientforschung Beiheft 19), pp. 8-15.

Meier, G. (1937): Die assyrische Beschwörungssammlung Maqlu. Berlin (Archiv für Orientforschung Beiheft 2).

Meier, G. (1941-1944): Die zweite Tafel der Serie bit meseri. Archiv für Orientforschung Vol. 14, pp. $139-152$.

Nikiprovetzky, V. (1975): Ethical Monotheism. Daedalus Vol. 104, No. 2, pp. 69-89.

Pardee, D. (2002): Ritual and Cult at Ugarit. Atlanta, Georgia, Society of Biblical Literature (Writings from the Ancient World 10).

Peter, H. J. (1999/2000): Astronomical Dating of Ur III and Akkad. Archiv für Orientforschung Vols 46/47, pp. 50-79.

Peterson, J. (2009): Godlists from Old Babylonian Nippur in the University Museum, Philadelphia. Münster, Ugarit-Verlag (Alter Orient und Altes Testament 362).

Podany, H. A. (2002): The Land of Hana. Kings, Chronology and Scribal Tradition. Bethesda, CDL Press.

Pomponio, F. - Xella, P. (1997): Les dieux d'Ebla. Étude analytique des divinités éblaites a l'époque des archives royales du IIIe millénaire. Münster, Ugarit-Verlag (Alter Orient und Altes Testament 245).

Postgate, J. N. (1994): In Search of the First Empires. Bulletin of the American School of Oriental Research Vol. 293, pp. 1-13.

Roberts, J. J. M. (1972): The Earliest Semitic Pantheon. Baltimore-London, The John Hopkins University Press. 
Sallaberger, W. (1999): Akkade-Zeit. In: Sallaberger, W.-Westenholz, A. (eds): Mesopotamien. Akkade-Zeit und Ur III-Zeit. Freiburg-Göttingen, Universitätsverlag Freiburg-Vandenhoeck \& Ruprecht (Orbis Biblicus et Orientalis 160), pp. 17-105.

Sallaberger, W. (2004): Relative Chronologie von der späten frühdynastischen bis zur altbabylonischen Zeit. In: Jan-Waalke, M. - Walter, S. (eds): 2000 v. Chr. Politische, wirtschaftliche und kulturelle Entwicklung im Zeichen einer Jahrtausendwende. Berlin, Saarbrücken Druckerei und Verlag (Colloquien der Deutschen Orient-Gesselschaft 3), pp. 15-43.

Stamm, J. J. (1939): Akkadische Namengebung. Leipzig, Hinrichs (Mitteilungen der Vorderasiatisch-Ägyptischen Gesellschaft 44).

Steinkeller, P. (2003): An Ur III Manuscript of the Sumerian King List. In: Sallaberger, W.- Volk, K.-Zgoll, A. (eds): Literatur, Politik und Recht in Mesopotamien. Festschrift für Claus Wilcke. Wiesbaden, Harrasowitz (Orientalia Biblica et Christiana 14), pp. 267-292.

Such-Gutierrez, M. (2005/2006): Untersuchungen zum Pantheon von Adab im 3. Jt. Archiv für Orientforschung Vol. 51, pp. 1-44.

Tropper, J. (1989): Nekromantie: Totenbefragung im Alten Testament. Kevelaer/NeukirchenVluyn, Butzon \& Bercker-Neukirchener Verlag (Alter Orient und Altes Testament 223).

van de Mieroop, M. (1999): Cuneiform Texts and the Writing of History. London-New York, Routledge (Approaching to the Ancient World 6).

van der Toorn, K. (1993): Ilib and the 'God of the Father'. Ugarit Forschungen Vol. 25, pp. 379387.

van der Toorn, K. (1996): Family Religion in Babylonia, Syria and Israel. Leiden-New YorkKöln, Brill (Studies in the History and Culture of the Ancient Near East 7).

Visicato, G. (1997): A Temple Institution in the Barley Records from Sargonic Ešnunna. Acta Sumerologica Vol. 19, pp. 235-259.

Vorländer, H. (1975): Mein Gott. Die Vorstellungen vom Persönlichen Gott im Alten Orient und im Alten Testament. Neukirchen-Vluyn, Neukirchener Verlag, Verlag Butzon \& Bercker Kevealer (Alter Orient und Altes Testament 23).

Wall-Romana, C. (1990): An Areal Location of Agade. Journal of Near Eastern Studies Vol. 49, pp. 205-245.

Westenholz, J. G. (1983): The Heroes of Akkad. Journal of the American Oriental Society Vol. 103, No. 1, pp. 327-336.

Westenholz, G. J. (1992): Oral Traditions and Written Texts in the Cycle of Akkade. In: Marianna, V. E.-Herman, V. L. J. (eds): Mesopotamian Epic Literature. Oral or Aural? LewistonQueenston-Lampeter, The Edwin Mellen Press, pp. 123-154.

Westenholz, J. G. (1997): Legends of the Kings of Akkade. The Texts. Winona Lake, Indiana, Eisenbrauns (Mesopotamian Civilizations 7).

Woods, C. E. (2004): The Sun-God Tablet of Nabû-apla-iddina Revisited. Journal of Cuneiform Studies Vol. 56, pp. 23-103.

Xella, P. (1995): Death and Afterlife in Canaanaite and Hebrew Thought. In: Sasson, M. J. - Baines, J. - Beckman, G. - Rubinson, K. (eds): Civilizations of the Ancient Near East. New York, Charles Scribner's Sons, pp. 2059-2070. 